\title{
Antidiabetic Activity of the Leaf Extract of Eurycoma Longifolia Jack. in Streptozotocin-Nicotinamide Induced Diabetic Model
}

\author{
Ruqiah Ganda Putri Panjaitan*, Agus Astuti
}

\section{Ruqiah Ganda Putri Panjaitan*,} Agus Astuti

Department of Biology Education, Faculty of Teacher Training and Education,

Tanjungpura University. Jl. Prof. Dr. H. Hadari Nawawi, Bansir Laut, Kec. Pontianak

Tenggara, Kota Pontianak, West Kalimantan 78124, INDONESIA.

\section{Correspondence}

Ruqiah Ganda Putri Panjaitan

Department of Biology Education,

Faculty of Teacher Training and Education,

Tanjungpura University. Jl. Prof. Dr.

H. Hadari Nawawi, Bansir Laut, Kec.

Pontianak Tenggara, Kota Pontianak, West

Kalimantan 78124, INDONESIA.

E-mail: ruqiah.gpp@fkip.untan.ac.id

History

- Submission Date: 25-09-2021;

- Review completed: 26-10-2021;

- Accepted Date: 02-11-2021.

DOI : 10.5530/pj.2021.13.203

Article Available online

http://www.phcogj.com/v13/i6

Copyright

(C) 2021 Phcogj.Com. This is an openaccess article distributed under the term of the Creative Commons Attribution 4.0 International license.

\begin{abstract}
Background: One of the medication attempts in diabetes mellitus is by utilising plants that are potent as an antioxidant. Eurycoma longifolia Jack. known as "Longjack" in English, is a medicinal plant and reportedly effective as an antioxidant. Objectives: This study was aimed to examine the antidiabetic effectiveness of ethanol extract of longjack leaf in diabetes mellitus rats. Methods: This study used the total of 24 male white rats which were grouped into four. The normal and the negative control groups were administrated with CMC-Na $0.5 \%$ dose $2 \mathrm{ml} / 200 \mathrm{~g}$ body weight; one group was administrated with ethanol extract of longjack leaf dose $176.4 \mathrm{mg} / 200 \mathrm{~g}$ body weight; and the positive control group was administrated with glibenclamide dose $0.09 \mathrm{mg} / 200 \mathrm{~g}$ body weight. Before the extract administration, all of the experimental animals were prior induced into diabetic condition with streptozotocin-nicotinamide. Results: The levels of blood glucose and malondialdehyde in rats after the 14-day extract treatments were $78.73 \mathrm{mg} / \mathrm{dl}$ and $1.13 \mathrm{nmol} / \mathrm{ml}$, respectively in the normal control group; $285.84 \mathrm{mg} / \mathrm{dl}$ and 10.03 $\mathrm{nmol} / \mathrm{ml}$ were in the negative control group; $156.77 \mathrm{mg} / \mathrm{dl}$ and $3.86 \mathrm{nmol} / \mathrm{ml}$ in the group with the administration of ethanol extract of longjack leaf; and $148.63 \mathrm{mg} / \mathrm{dl}$ dan $3.64 \mathrm{nmol} / \mathrm{ml}$ in the group of glibenclamide administration $(p<0.05)$. The reduction of blood glucose and malondialdehyde levels in the groups of ethanol extract administration of longjack leaf dose $176.4 \mathrm{mg} / 200 \mathrm{~g}$ body weight was similar to the glibenclamide administration dose $0.09 \mathrm{mg} / 200 \mathrm{~g}$ body weight. Conclusion: The ethanol extract of longjack leaf was effective as an antidiabetic.
\end{abstract}

Key words: Blood glucose level, Diabetes mellitus, Eurycoma longifolia Jack. leaf.

\section{INTRODUCTION}

Diabetes mellitus is a syndrome of metabolic disorder of carbohydrates, lipids, and proteins occurring as a result of insulin limitation and the decline of tissue sensitivity against insulin. Diabetes mellitus causes hyperglycaemia, lipid abnormality, and other metabolic disorders. ${ }^{1-3}$ Diabetes is classified into two types, i.e. diabetes type 1 and type 2 . Diabetes type 1 is noticeable with the destruction of autoimmune of pancreatic $\beta$ cells, which are an insulin producer, ${ }^{4}$ whereas diabetes type 2 is manifested due to the occurrence of hyperglycaemia which is caused by the reduction of insulin secretion triggered by the resistance of insulin., ${ }^{5,6}$ Diabetes mellitus type 2 is a health problem faced by the worldwide community and closely related to obesity, hypertension, and other health diseases; this condition may even become worse resulting in serious complication on other organs in the body, such as heart attack, heart failure, kidney failure, dementia, blindness, and lower limb amputations.?

Previous studies revealed that one of the triggered factors in hyperglycaemia is the upsurge of free radical production or reactive oxygen species (ROS); the intensification of ROS activity can injure various tissues in the body, ${ }^{6,8-10}$ Moreover, the hyperglycaemia condition also promotes the increase of ROS production in all tissues through the process of glucose auto-oxidation and protein glycosylation. Meanwhile, in the oxidative stress condition, the levels of antioxidant enzymes extensively affect the susceptibility of various tissues associated to complications in patients with diabetes. ${ }^{6,8-10}$ The main target of ROS is lipid, and one of the decomposition products from lipid oxidation is malondialdehyde, which is formed from prostaglandin biosynthesis, such as endoperoxides from polyunsaturated fatty acids. ${ }^{6,9,11}$ Previously, it has been reported that malondialdehyde is systematically linked to metabolic parameters in patients with diabetes type 1 and 2 , and is stated that the patients with diabetes in severe metabolic control will show the high plasma levels of malondialdehyde and are significantly different with diabetic patients in better metabolic control. ${ }^{12}$ In the hyperglycaemia condition, the rise of ROS production exceeding the antioxidant capacity of cells will lead to the escalation of oxidative stress accompanied by the lipid peroxidase in cell membranes so that it will increase malondialdehyde as a result of lipid peroxidation. ${ }^{13}$

Medicinal plants are reported to containing various secondary metabolites that play a role as antioxidant. Antioxidant is a vital substance that protects our body from damages due to oxidative stress by free radicals. ${ }^{14-16}$ Several studies showed that some plants are widely contributed in diabetes management because the phytochemical compounds have potency as an antioxidant, anti-inflammation, and the decline of blood glucose. ${ }^{17,18}$ There are plants available in diabetes medication, such as ladies' fingers seed (Abelmoschus esculentus) ${ }^{16}$ and longjack $\operatorname{root}$ (Eurycoma longifolia Jack.). ${ }^{19}$

Indonesia is one of the countries that has massive biodiversity and local knowledge correlated to the utilisation of medicinal plants. ${ }^{20,21}$ Eurycoma longifolia Jack. which is classified into Simaroubaceae 
family, is one of the famous medicinal plants in the Southeast Asia. ${ }^{22,23}$ Longjack is also one of the Indonesia's tropical plants and well known as a raw material in the manufacture of both modern and traditional drugs. Previous studies demonstrated various medicinal activities from the longjack root, such as anti-hyperlipidaemia, anti-inflammation, and analgesic ${ }^{24}$; anti-obesity ${ }^{25}$; hepatoprotector ${ }^{14}$, and were safely proven in blood profile of lactating mothers. ${ }^{26}$ Not only that, the longjack root is also a plant used in traditional medicine to treat diabetes mellitus. ${ }^{23}$ In accordance with the diverse activities owned by the longjack root, the study results of qualitative phytochemicals exhibited that methanol extract of the longjack root contained phenol, flavonoid, terpenoid, glycoside, cardiac glycosides, and protein. ${ }^{27}$ On the other side, Kaimal et al. (2010) ${ }^{28}$ stated that the responsible compounds for decreasing blood glucose level are flavonoid, phenol, diterpenoid, triterpenoid, glycoside, and steroid.

The findings revealed that any phytochemical compounds in a plant are not only concentrated in certain parts of the organs, but also in specific areas. If a plant has compounds in certain parts, it may be considered that other parts have also similar compounds even in different levels. ${ }^{29}$ Currently, the longjack's organ often used is the root. ${ }^{14,26,30,31,32}$ However, if this part is excessively used in future, it may have an adverse impact on the survival of this plant species. Therefore, it is necessarily conducted a research to investigate another part of the plant's organ, which is the leaf. Several studies related to the longjack plant demonstrated that the longjack leaf can be used to treat itching; the fruit is efficacious for dysentery; the stem bark is useful for worms ${ }^{23}$; the petiole has the activity of healing the cut wounds in mice. ${ }^{33}$ Furthermore, it is stated that this healing power is correlated to the content of compounds in the longjack leaf. ${ }^{33}$ In connection with this, the aim of this study was to determine the antidiabetic activity of ethanol extract of longjack leaf in streptozotocin-nicotinamide induced rats.

\section{MATERIALS AND METHODS}

\section{Experimental Animals}

All experimental animals used in this study were the male white Wistar rats aged 2 months with the body weights ranging from $148-209 \mathrm{~g}$. Those animals were collected from the laboratory of The Centre for Food and Nutrition Studies, University of Gadjah Mada, Yogyakarta, Indonesia. Before treatments began, all rats were acclimatised for 7 days. During this acclimatisation period, they were fed with standard diet of ayam Bangkok AD II and drunk ad libitum. Overall procedures related to the management of animal model in this study was ethically approved in the letter of 1.253/XI/HREC/2019 from the Ethic Commission of Health Research of Regional Public Hospital (RSUD) Dr. Moewardi, Surakarta, Indonesia.

\section{Plant Extraction}

The fresh longjack leaves were collected from Peramas Mount, Mount Palung National Park, North Kayong Regency, West Kalimantan, Indonesia. The result of plant determination was stated in a letter numbered 123/A/LB/FMIPA/UNTAN/2018. The leaves were then separated from the stalks, cleansed, and weighted for the wet weight of $4.2 \mathrm{~kg}$. After that, they were dried and collected the dry weight of $1.55 \mathrm{~kg}$. Next, the leaves were extracted using $96 \%$ distilled ethanol solvent. The yielding of samples was conducted in room temperature for $24 \mathrm{~h}$ with threefold repetitions. The filtrates of the sample yields were then evaporated using vacum rotary evaporator. The extract total obtained was $62.2 \mathrm{~g}$ with the yield of $4.02 \%$. The extraction process was conducted in this study following to Harborne (1987). ${ }^{34}$

\section{Production of CMC-Na 0,5\% Solution}

All procedures of the production of CMC-Na 0,5\% solution referred to Salma et al. (2013)..$^{35}$ A total of $0.5 \mathrm{~g} \mathrm{CMC-Na} \mathrm{(Sigma-Aldrich)} \mathrm{was}$ placed into a beaker glass and dissolved in $\pm 30 \mathrm{~mL}$ warm aquades until homogenised. The homogenous CMC-Na solution was then moved to a $100 \mathrm{ml}$ volumetric flask, added by aquades till $100 \mathrm{ml}$, and stirred up until well-mixed. The dosage used in this trial followed Saputri \& Zahara $(2016)^{36}$ at $2 \mathrm{ml} / 200 \mathrm{~g}$ body weight.

\section{Production of Streptozotocin Solution}

Streptozotocin (STZ) solution and dosages were correspondingly made following Ghasemi et al. ${ }^{37}$ A total of $216 \mathrm{mg}$ streptozotocin (Cayman Chemical) was diffused in $72 \mathrm{ml}$ buffer citrate with $\mathrm{pH} 4.5$, which was initially prepared before inoculation. Then, the homogenisation was done by homogeniser. The dosage of streptozotocin solution used in the injection was $9 \mathrm{mg} / 200 \mathrm{~g}$ body weight.

\section{Production of Nicotinamide Solution}

Dosages and NA (Nicotinamide) solution were prepared according to the method of Ghasemi et al.(2014). ${ }^{37} \mathrm{~A}$ total of $528 \mathrm{mg}$ nicotinamide (Sigma-Aldrich) was suspended in $72 \mathrm{ml}$ sodium chloride $0.9 \%$ (PT Widrata Bhakti) until homogenous using homogeniser. Nicotinamide dose injected to the rats was $22 \mathrm{mg} / \mathrm{kg}$ body weight.

\section{Production of Glibenclamide Suspension}

Glibenclamide suspension and dosage administration were implemented using the method of Salma et al. (2013). ${ }^{35}$ The dose administration of glibenclamide (PT Indofarma) for adults is $5 \mathrm{mg}$. Thus, the rat dosage conversion is $0.09 \mathrm{mg} / 200 \mathrm{~g}$ body weight. A glibenclamide tablet (PT Indofarma) of $27 \mathrm{mg}$ was ground using mortar, then was diffused in $15 \mathrm{ml}$ of CMC-Na $0.5 \%$.

\section{Rat Models with Diabetes Mellitus type 2}

Induction procedure of type- 2 diabetes mellitus in rats referred to Ghasemi et al. (2014). ${ }^{37}$ Rats were injected via intraperitoneal with the combination of streptozotocin dose $9 \mathrm{mg} / 200 \mathrm{~g}$ body weight and nicotinamide dose $22 \mathrm{mg} / 200 \mathrm{~g}$ body weight which was early administered 15 mins before streptozotocin.

\section{Antidiabetic Activity Test}

Rats were divided into 4 groups consisting of 6 . The first group was the normal control; the second one was negative control with CMC$\mathrm{Na} 5 \%$ dose $2 \mathrm{ml} / 200 \mathrm{~g}$ body weight; the third one was the group with the ethanol extract administration of longjack leaf dose $176.4 \mathrm{mg} / 200$ g body weight; and the fourth one was the positive control with the glibenclamide administration dose $0.09 \mathrm{mg} / 200 \mathrm{~g}$ body weight. After acclimatisation, on the 0 day the initial blood draw was done when all experimental animals were yet to receive treatments. Then, they were induced with STZ-NA. The induction of STZ-NA was completed by injecting streptozotocin dose $9 \mathrm{mg} / 200 \mathrm{~g}$ body weight and nicotinamide dose $22 \mathrm{mg} / 200 \mathrm{~g}$ body weight via intraperitoneal. Nicotinamide was given 15 mins early before streptozotocin. Next, on the day 3 the second blood draw was performed to investigate blood glucose levels after injections. According to Ghasemi et al.(2014) ${ }^{37}$ rats considered to have type 2 diabetic condition are when the blood glucose levels $>250$ $\mathrm{mg} / \mathrm{dl}$. In this study, all of blood glucose levels in the rats after injections were above the normal rate of $200 \mathrm{mg} / \mathrm{dl}$. Hence, this study was then continued to the next steps of the extraction administration for 14 days consecutively from the day 4 to 17 . On the day 18 , the last blood draw was performed to determine blood glucose and malondialdehyde levels after the treatments. All rats were prior fasted for \pm 12 - $15 \mathrm{~h}$ when each blood draw implemented. 


\section{Measurement of Blood glucose Levels}

Blood sample in rats were obtained from sinus orbitalis using microhematocrit. The collected blood samples were placed into eppendorf tubes and centrifuged at $4000 \mathrm{rpm}$ for 15 mins. After the serums were parted, the serum separation was done by adding glucoses GOD FS DiaSys into test tubes. The samples in the test tubes were then homogenised using vortex. The absorbance measurement was completed by using spectrophotometer at $500 \mathrm{~nm}$.

\section{Measurement of Malondialdehyde Levels}

Measurement of malondialdehyde levels in blood serum was finalised using the method of Thiobarbituric Acid Reactive Subtance. A total of $0.5 \mathrm{ml}$ blood serum was added with $0.5 \mathrm{ml}$ trichloroacetic acid $30 \%$ and centrifuged at $3000 \mathrm{rpm}$ for 5 mins. Supernatant was then collected. A total of $0.5 \mathrm{TBA} 10 \%$ was added into 0.5 supernatant and boiled at $100^{\circ} \mathrm{C}$ for 30 mins, then was cooled at room temperature. The absorbance was then read at $532 \mathrm{~nm}$. Malondialdehyde concentration is $\mu \mathrm{l} / 1 \mathrm{ppm}$.

\section{Data Analysis}

This study was conducted using completely randomised design. Overall, the data was statistically analysed using SPSS 24 for Windows and continued with the Duncan test at a confidence rate of 5\%.

\section{RESULTS AND DISCUSSION}

The treatment of diabetes mellitus can be done using medicinal plants. Some plants having the antioxidant content of flavonoid, tannin, alkaloid, and terpenoid are reportedly efficacious in decreasing blood glucose level. ${ }^{38,39}$ Longjack or pasak bumi is a medicinal plant used in herbal medicine because of the potential properties, such as antidiabetic. ${ }^{23}$ Methanol extract of the longjack root was reported to have compounds of phenol, flavonoid, heart glycosides, protein, and terpenoid. ${ }^{27}$ The use of longjack is more concentrated on the root, while the leaf is still rare to be used. ${ }^{14,26,27}$ Therefore, this study was focused to evaluate the antidiabetic activity of ethanol extract of longjack leaf in streptozotocin-nicotinamide induced rats. According to Mahajan et al. $(2020)^{10}$; Szkudelski $(2012)^{40}$ the streptozotocin administration was reported to damage pancreatic $\beta$ cells by forming free radicals, similarly nature impairments occur in diabetes. Moreover, the decline of blood glucose levels made malondialdehyde levels also decreased. ${ }^{12}$ Table 1 and 2 displayed the test results of antidiabetic activity of ethanol extract of longjack in STZ-NA induced rats.
Diabetes mellitus is marked with hyperglycaemia condition which causes oxidative stress. This condition will encourage the formation of ROS in various tissues through the auto-oxidation process. Reactive oxygen species will straightforwardly oxidase and damage DNA, protein, lipid which ended up with complications due to diabetes. ${ }^{41}$ In hyperglycaemia condition, the increase of ROS production exceeding the antioxidant capacity of cells will initiate oxidative stress accompanied by the occurrence of lipid peroxidation in cell membranes so that it will increase malondialdehyde as a result of lipid peroxidation ${ }^{13}$ and injuries in tissue cells. ${ }^{42}$ Other study results also proved that species oxyegn reactive plays a main role in the pathogenesis of type-2 diabetes mellitus. ${ }^{10,40}$ On the other side, the escalation of malondialdehyde levels is a result of the rise of ROS production so that malondialdehyde becomes one of the probes to identify the oxidative stress in cells. The measurement of malondialdehyde is not only through plasma and serum, but also from various tissues in kidney tissues in patients with diabetes. $^{9}$

According to Hidayaturrahmah et al. $(2020)^{43}$ blood glucose levels in normal rats ranged from $50-135 \mathrm{mg} / \mathrm{dl} .{ }^{43} \mathrm{In}$ Table 1 , it can be seen that the average levels of blood glucose on the day 0 for all treatments were in normal rates, $66.29-68.40 \mathrm{mg} / \mathrm{dl}$. Similarly, in the same table, it was also shown that blood glucose levels in the experimental rats in the normal control on the measurement day 0,3 , and 18 were in normal rates; these groups shown to imply that all animal models were not diabetic without STZ-NA induction. Thereafter, on the day 3 another blood draw was carried out to investigate the escalation of blood glucose levels due to STZ-NA induction. The results demonstrated that the average levels of blood glucose in animal models on the groups with the administration of CMC-Na, ethanol extract of longjack, and glibenclamide were 277.19-281.04 mg/dl, implying that all experimental animals had type2 diabetes mellitus. In accordance with Ghasemi et al. (2014) $)^{37}$ it stated that if blood glucose levels in rats $>250 \mathrm{mg} / \mathrm{dl}$ after STZ-NA injection indicating all rats had type 2 diabetes mellitus. ${ }^{37}$ This occurred because of streptozotocin injection will expand the capacity of free radicals due to the release of oxide nitrogen radicals so that it leads damages in pancreatic $\beta$ cells. $^{37}$ In contrast, nicotinamide is an antioxidant of vitamin B3 derivate (Niasin) which acts to protect pancreatic $\beta$ cells from the adverse effects of streptozotocin cytotoxic. ${ }^{37}$ In connection with the nicotinamide role, the aim of nicotinamide administration in this study was to prevent streptozotocin from damaging DNA that might lead to massive destruction in pancreatic $\beta$ cells. Moreover, on

Table 1. Average levels of blood glucose in rats on each treatment group on the day 0,3 , and 18.

\begin{tabular}{|c|c|c|c|}
\hline \multirow{2}{*}{ Treatment Group } & \multicolumn{3}{|c|}{ Average Levels of Blood Glucose (mg/dl) } \\
\hline & D-0 & D-3 & D-18 \\
\hline Normal Control & $66.36^{\mathrm{a}} \pm 1.42$ & $67.54^{\mathrm{a}} \pm 1.23$ & $78.73^{\mathrm{a}} \pm 7.20$ \\
\hline CMC-Na $5 \%$ dose $2 \mathrm{ml} / 200 \mathrm{~g}$ body weight & $66.29^{\mathrm{a}} \pm 1.87$ & $277.19^{\mathrm{b}} \pm 3.01$ & $285.84^{\mathrm{c}} \pm 17.56$ \\
\hline $\begin{array}{l}\text { Ethanol Extract of Longjack Leaf dose } 176.4 \\
\mathrm{mg} / 200 \mathrm{~g} \text { body weight }\end{array}$ & $68.40^{\mathrm{a}} \pm 1.71$ & $281.04^{c} \pm 1.79$ & $156.77^{\mathrm{b}} \pm 8.49$ \\
\hline $\begin{array}{l}\text { Glibenclamide dose } 0.09 \mathrm{mg} / 200 \mathrm{~g} \text { body } \\
\text { weight }\end{array}$ & $67.16^{\mathrm{a}} \pm 2.27$ & $279.28^{b, c} \pm 3.30$ & $148.63^{\mathrm{b}} \pm 23.81$ \\
\hline
\end{tabular}

Information: * Same letters shown not significantly different on the Duncan test at 5\%

Numbers shown after \pm demonstrated SD (Standard Deviation)

Table 2. Average levels of malondialdehyde on each treatment group on the day 18.

\begin{tabular}{lc} 
Treatment Group & Malondialdehyde Level $(\mathrm{nmol} / \mathrm{ml})$ \\
\hline Normal Control & $1.13^{\mathrm{a}} \pm 0.22$ \\
$\mathrm{CMC}-\mathrm{Na} 5 \%$ dose $2 \mathrm{ml} / 200 \mathrm{~g}$ body weight & $10.03^{\mathrm{c}} \pm 0.34$ \\
Ethanol Extract of Longjack Leaf dose $176.4 \mathrm{mg} / 200 \mathrm{~g}$ body weight & $3.86^{\mathrm{b}} \pm 0.71$ \\
Glibenclamide dose $0.09 \mathrm{mg} / 200 \mathrm{~g}$ body weight & $3.64^{\mathrm{b}} \pm 1.77$
\end{tabular}

Information: * Same letters shown not significantly different on the Duncan test at 5\%

Numbers shown after \pm demonstrated SD (Standard Deviation) 
the day 18 the measurement of blood glucose and malondialdehyde levels was recorded to determine the antidiabetic activity of ethanol extracts. The findings revealed that the average levels of blood glucose on the day 18 ranged from $148.63-285,84 \mathrm{mg} / \mathrm{dl}$, suggesting the decline of blood glucose levels on the groups with the administration of glibenclamide and longjack ethanol extract. Conversely, the elevation of blood glucose levels occurred in the group of CMC-Na injection.

Table 2 presented the average levels of malondialdehyde from all treated groups ranging from $1.13-10.03 \mathrm{nmol} / \mathrm{ml}$, implying that malondialdehyde levels in the experimental rats on the normal control were at normal rates. In contrast, the groups with the injections of CMC-Na, longjack ethanol extract, and glibenclamide experienced declines. Responding to Sutaryono et al. $(2016)^{44}$ the normal levels of malondialdehyde are $1.09-1.64 \mathrm{nmol} / \mathrm{ml}^{4}{ }^{44}$ Malondialdehyde is a product of lipid peroxidation generally used as an indicator of the occurrence of oxidative stress. ${ }^{45}$ Normal group showed the levels of blood glucose in normal rates and had the lowest level of malondialdehyde compared to other groups $(1.13 \mathrm{nmol} / \mathrm{ml})$; this group was not exposed by streptozotocin. Fitriana et al. $(2017)^{46}$ disclosed that streptozotocin can advance lipid peroxidation and malondialdehyde level. ${ }^{46}$ More than that, the balance between free radicals and antioxidant can be found in the normal body. Nevertheless, the balance can change when the production of free radicals rose; stress oxidative is a product of the imbalance. Stress oxidative can occur due to free radical upsurge or the decline of antioxidant activity, nor can be both. ${ }^{8}$ On the group with CMC-Na administration, the blood glucose levels elevated joining with the highest level of malondialdehyde at $10.03 \mathrm{nmol} / \mathrm{ml}$. Unfortunately, CMC-Na does not have any potential compounds that can reduce both blood glucose and malondialdehyde levels. Fitriana et al. $(2017)^{46}$ stated that streptozotocin will improve lipid peroxidation and malondialdehyde level, while Dewi et al. (2016) ${ }^{47}$ confirmed that CMC-Na has also no beneficial substances that are capable of overcoming streptozotocin effects. On the groups with the administration of glibenclamide experienced the reduction of blood glucose and malondialdehyde levels. Glibenclamide is reported to have stimulus effects on pancreatic $\beta$ cells to secrete insulin so that it can downgrade blood glucose rates. ${ }^{48}$ Furthermore, on the group with the administration of longjack ethanol extract had an activity of protection for the body from free radical attacks caused by streptozotocin. This was noticeable of the decrease of blood glucose and malondialdehyde levels. Khanam et al. $(2014)^{27}$ revealed that the longjack root has the contents of phenolate, flavonoid, and terpenoid. Moreover, Panjaitan et al. $(2020)^{33}$ also disclosed that the ethanol extract of longjack stalks has the contents of alkaloid, terpenoid, saponin, tannin, and phenol. All metabolite secondary contents in various organs of the plant are reported to have antioxidant properties. Flavonoid is reported to have an ideal structure as an antioxidant to block free radicals. The structure is combined with the group of phenol which is composed by more than one aromatic and hydroxyl groups as well as conjugated double bonds where the structure is required in capturing free radicals. ${ }^{49}$ Flavonoid can also provide beneficial effects for diabetes by motivating insulin secretion and the proliferation of pancreatic $\beta$ cells, lessening apoptosis, treating hyperglycaemia through the management of glucose metabolism in hepatocytes, diminishing insulin resistance, inflammation, and oxidative stress in muscles and lipids, as well as increasing the glucose absorption in skeletal muscles and white adipose tissues. ${ }^{41}$ Flavonoid also has a potential property in stabilising the products of the regeneration process of peroxyl and hydroxyl radicals. Stability of phenoxy radicals is believed to slow the speed of propagation reaction on the process of lipid auto-oxidation..$^{44}$ Meanwhile, alkaloid is believed to reduce blood glucose level..$^{50,51,52}$ Therefore, the results of this study suggested the antidiabetic effect of ethanol extract of longjack assessed by the levels of blood glucose and malondialdehyde. In addition, the potential properties are confirmed by the antioxidant contents found in the ethanol extract of longjack so that it may repair damages due to free radical attacks.

\section{CONCLUSION}

Ethanol extract of the longjack leaf dose $176.4 \mathrm{mg} / 200 \mathrm{~g}$ body weight has an antidiabetic property in terms of reducing blood glucose and malondialdehyde levels in streptozotocin induced rats, which is equivalent to the administration of glibenclamide dose $0.09 \mathrm{mg} / 200 \mathrm{~g}$ body weight.

\section{REFERENCES}

1. Abel-salam BKA. Immunomodulatory effects of black seeds and garlic on alloxan-induced diabetes in albino rat. Allergol Immunopathol J. 2012;40(6):336-40. doi: 10.1016/j.aller.2011.07.002.

2. Yang J, Zhao P, Wan D, Zhou O, Wang C, Shu G, et al. Antidiabetic effect of methanolic extract from Berberis julianae Schneid. via activation of AMP-activated protein kinase in type 2 diabetic mice. Evidence-based Complement Altern Med. 2014;2014:1-12. doi: 10.1155/2014/106206.

3. Zolghadr L, Farahani BV, Ghasemzadeh H, Javadi N. Physicochemical studies of closed loop insulin delivery system based on intelligent carboxymethyl cellulose hydrogel. Indian $\mathrm{J}$ Biochem Biophys. 2019;56:125-31. http://op.niscair.res.in/index.php/IJBB/article/ view/27658.

4. Melkonyan AM, Guevorkyan AG, Khalchujyan N, Hovhannisyan MR, Movsesyan $\mathrm{NH}$, Hayrapetyan $\mathrm{HL}$, et al. Sex and age-related changes in L-arginine metabolism in peripheral blood leukocytes in young caucasians with type 1 diabetes mellitus. Indian J Biochem Biophys. 2020;57(3):339-50. http://op.niscair.res.in/index.php/lJBB/article/ view/36729.

5. American Diabetes Association. Standards of Medical Care in Diabetes - 2015. Diabetes Care. 2015;38(1):1-94.

6. Mistry KN, Dabhi BK, Joshi BB. Evaluation of oxidative stress biomarkers and inflammation in pathogenesis of diabetes and diabetic nephropathy. Indian J Biochem Biophys. 2020;57(1):45-50. https://www.researchgate.net/publication/343827472.

7. Majnarić LT, Babic F, Bosnic Z, Zekic-Susac M, Wittlinger T. Diabetes and clinical research the use of artifical intelligence in assessing glucose variability in individuals with diabetes type 2 from routine primary care data. Int J Diabetes Clin Res. 2020;7(2):1-12. doi: 10.23937/2377-3634/1410121.

8. Kangralkar, V A, Patil, S D, Bandivadekar, R M. Oxidative stress and diabetes: a review. Int J Pharm Appl. 2010;1(1):38-45.

9. Tiwari BK, Pandey KB, Abidi, A B, Rizvi I. Markers of Oxidative Stress during Diabetes Mellitus. J Biomarkers. 2013;2013:1-8. http://dx.doi. org/10.1016/j.jsps.2015.03.013.

10. Mahajan MS, Upasani CD, Upaganlawar AB, Gulecha VS Renoprotective effect of Co-enzyme $\mathrm{Q} 10$ and $\mathrm{N}$-acetylcysteine on streptozotocin-induced diabetic nephropathy in rats. Int J Diabetes Clin Res. 2020;7(2):1-12. doi: 10.23937/2377-3634/1410123.

11. Tangvarasittichai $S$, Poonsub $P$, Tangvarasittichai $O$, Sirigulsatien V. Serum levels of malondialdehyde in type 2 diabtes mellitus thai subjects. Siriraj Med J. 2009;61:20-3. https://www.researchgate.net/ publication/285772939.

12. Nakhjavani M, Esteghamati A, Nowroozi S, Asgarani F, Rashidi A Khalilzadeh O. Type 2 diabetes mellitus duration: An independent predictor of serum malondialdehyde levels. Singapore Med J. 2010;51(7):582-5. https://pubmed.ncbi.nlm.nih.gov/20730399/.

13. Soviana E, Rachmawati B, Widyastiti NS. Pengaruh suplementasi $\beta$-carotene terhadap kadar glukosa darah dan kadar malondialdehida pada tikus sprague dawley yang diinduksi Streptozotocin. J Gizi Indones (The Indones J Nutr). 2014;2(2):41-6. https://doi.org/10.14710/ jgi.2.2.41-46. 
14. Panjaitan RGP, Handharyani E, Chairul, Manalu W. Hepatoprotective activity of Eurycoma longifolia Jack. roots. Indian J Tradit Knowl. 2013;12(2):225-30. https://www.researchgate.net/publication/286062082.

15. Naimi M, Vlavcheski F, Shamshoum H, Tsiani E. Rosemary extract as a potential anti-hyperglycemic agent: Current evidence and future perspectives. Nutrients. 2017;9(968):1-19. doi: 10.3390/nu9090968.

16. Dubey P, Mishra S. Effect of okra seed in treatment of hypoglycemia : A research framework using STZ induced rat Effect of okra seed in treatment of hypoglycemia : A research framework using STZ induced rat. J Med Plants Stud. 2018;6(3):85-8. https://www.researchgate. net/publication/342121305.

17. ZhangW, Zhao J, Wang J, Pang X, Zhuang X, Zhu X, et al. Hypoglycemic effect of aqueous extract of seabuckthorn (Hippophae rhamnoides L.) seed residues in streptozotocin-induced diabetic rats. Phyther Res. 2010;24:228-32. doi: 10.1002/ptr.2917.

18. Ungurianu A, Şeremet O, Gagniuc E, Olaru OT, Guţu C, Grădinaru $D$, et al. Preclinical and clinical results regarding the effects of a plant-based antidiabetic formulation versus well established antidiabetic molecules. Pharmacol Res. 2019;150:1-61. doi: https:// doi.org/10.1016/j.phrs.2019.10452219.

19. Fransisca F, Kalangi GE, Candrasari DS, Hendra P. the Effect of Pasak Bumi Roots Towards Blood Glucose Level in Glucose-Loaded Mice. J Pharm Sci Community. 2018;15(1):1-6. doi: http://dx.doi.org/10.24071/ jpsc. 151965.

20. Hayati KE, Jannah A, Ningsih R. Identifikasi senyawa dan aktivitas antimalaria in vivo ekstrak etil asetat tanaman anting-anting (Acalypha indica L.). Molekul. 2012;7(1):20-32. https://www.researchgate.net/ publication/313813309.

21. Panjaitan RGP, Mitalia, Partasasmita R. Indigenous knowledge of the people in Karya Usaha hamlet (Kubu Raya, West kalimantan, Indonesia) on the processing and diversity of plants that enhance toddler's appetite. Biodiversitas. 2020;21(9):4284-90. doi: 10.13057/ biodiv/d210946.

22. Khanijo T, Jiraungkoorskul W. Review ergogenic effect of long jack, Eurycoma longifolia. Pharmacogn Rev. 2016;10(20):139-42. doi: 10.4103/0973-7847.194041.

23. Rehman SU, Choe K, Yoo HH. Review on a traditional herbal medicine, Eurycoma longifolia Jack (Tongkat Ali): Its traditional uses, chemistry, evidence-based pharmacology and toxicology. Molecules. 2016;21(3). doi: 10.3390/molecules21030331.

24. Hendra PF, Andreani PR, Pangestuti BME, Julianus J. Evaluation of Antihyperlipidemic, Anti-Inflammatory, and Analgesic Activities of Eurycoma longifolia in Animal Models. Int J Pharm Pharm Sci. 2017:9(3):166-9. doi: 10.22159/ijpps.2017v9i3.16366.

25. Lahrita L, Hirosawa R, Kato E, Kawabata J. Isolation and lipolytic activity of eurycomanone and its epoxy derivative from Eurycoma longifolia. Bioorg Med Chem. 2017;25(17):4829-34. http://dx.doi. org/10.1016/j.bmc.2017.07.032

26. Panjaitan RGP, Zulfan. The effect of administration of pasak bumi (Eurycoma longifolia Jack.) roots to haematological profile of lactating mice. Indian J Tradit Knowl. 2015;14(2):231-5. https://www. researchgate.net/publication/282954837.

27. Khanam Z, Wen CS, Bhat IUH. Phytochemical screening and antimicrobial activity of root and stem extracts of wild Eurycoma longifolia Jack (Tongkat Ali). J King Saud Univ - Sci. 2014;27(1):23-30. http://dx.doi.org/10.1016/j.jksus.2014.04.006.

28. Kaimal S, Sujatha KS, George S. Hypolipidaemic and antioxidant effects of fruits of Musa AAA (chenkadali) in alloxan induced diabetic rats. Indian J Exp Biol. 2010;48(2):165-73. https://pubmed.ncbi.nlm. nih.gov/20455326/.

29. Amir MN, Sulitiani Y, Pratiwi I, Wahyudin E, Manggau MA, Ismail S. Aktivitas anti diabetes mellitus tanaman durian (Durio zibethinus Murr.) terhadap kadar glukosa darah puasa mencit yang diinduksi aloksan. Maj Farm dan Farmakol. 2020;23(3):75-8. doi: 10.20956/mff.v23i3.9396.
30. Kavitha N, Noordin R, Kit-Lam C, Sasidharan S. Real time antiToxoplasma gondii activity of an active fraction of Eurycoma longifolia root studied by in situ scanning and transmission electron microscopy. Molecules. 2012;17(8):9207-19. doi:10.3390/molecules17089207.

31. Low BS, Das PK, Chan KL. Standardized quassinoid-rich Eurycoma longifolia extract improved spermatogenesis and fertility in male rats via the hypothalamic-pituitary-gonadal axis. J Ethnopharmacol. 2013;145(3):706-14. http://dx.doi.org/10.1016/j.jep.2012.11.013.

32. Varghese CP, C A, Jin SC, Lim YJ, Keisaban T. Antioxidant and antiinflammatory activity of Eurycoma longifolia Jack, a traditional medicinal plant in Malaysia. Int $J$ Pharm Sci Nanotechnol. 2013;5(4):1875-8. doi: 10.37285/ijpsn.2012.5.4.7.

33. Panjaitan RGP, Maulidya A, Raharjeng ARP, Chakma S. Healing capacity of leaves stalks extract of pasak bumi (Eurycoma longifolia Jack.) on incised wounds of mice skin. Pharmacogn J. 2020;12(6):1351-6. doi: $10.5530 /$ pj.2020.12.186.

34. Harborne JB. Metode Fitokimia: Penuntun Cara Modern Menganalisis Tumbuhan. 2nd ed. Kosasi PN SI, editor. Bandung: ITB Press; 1987.

35. Salma N, Paendong J, Momuat LI, Togubu S. Antihiperglikemik ekstrak tumbuhan suruhan (Peperomia pellucida [L.] Kunth) terhadap tikus wistar (Rattus norvegicus L.) yang diinduksi sukrosa. J IIm Sains. 2013;13(2):116-23. doi: 10.35799/jis.13.2.2013.3055.

36. Saputri FC, Zahara R. Uji aktivitas anti-inflamasi minyak atsiri daun kemangi (Ocimum americanum L.) pada tikus putih jantan yang diinduksi karagenan. Pharm Sci Res. 2016;3(3):107-19. doi: 10.7454/ psr.v3i3.3619.

37. Ghasemi A, Khalifi S, Jedi S. Streptozotocin-nicotinamide-induced rat model of type 2 diabetes. Acta Physiol Hung. 2014;101(4):408-20. doi: 10.1556/APhysiol.101.2014.4.2.

38. Asante D, Effah-yeboah E, Barnes P, Abban HA, Ameyaw EO, Boampong JN, et al. Antidiabetic effect of young and old ethanolic leaf extracts of Vernonia amygdalina: A comparative study. J Diabetes Res. 2016;2016:1-12. http://dx.doi.org/10.1155/2016/8252741.

39. Hammeso WW, Emiru YK, Getahun KA, Kahaliw W. Antidiabetic and antihyperlipidemic activities of the leaf latex extract of Aloe megalacantha Baker (Aloaceae) in streptozotocin-induced diabetic model. Evidence-based Complement Altern Med. 2019;2019:1-9. doi: $10.1155 / 2019 / 8263786$.

40. Szkudelski T. Streptozotocin-nicotinamide-induced diabetes in the rat. Characteristics of the experimental model. Exp Biol Med. 2012;237(5):481-90. doi: 10.1258/ebm.2012.011372.

41. Lavle N, Shukla P, Panchal A. Role of flavonoids and saponins in the treatment of diabetes mellitus. J Pharm Sci Biosci Res. 2016;6(64):535-41. http://www.jpsbr.org/volume_6/JPSBR_Vol_6_ Issue_1_htm_files/JPSBR16RS4020.pdf.

42. Suparman E. Kadar lipid peroksida pada kehamilan normotensi dan preeklampsia. Maj Obstet Ginekol. 2012;20:65-71.

43. Hidayaturrahmah, Budi Santoso H, Aulia Rahmi R, Kartikasari D. Blood glucose level of white rats (Rattus norvegicus) after giving catfish biscuit (Pangasius hypothalmus). BIO Web Conf. 2020;20:1-4 doi: 10.1051/bioconf/20202004005.

44. Sutaryono, Andasari SD, Hidayati N. Pengaruh pemberian campuran bee polen, rimpang kencur, kunyit dan biji pinang terhadap penurunan kadar malondialdehida (MDA) pada tikus wistar pasca paparan streptozotocin. In: The 3 rd Universty Research Colloquium 2016. 2016. p. 496-504. https://jurnal.unimus.ac.id/index.php/psn12012010/ article/view/1615.

45. Vera B, Azhar A, Karmil TF, Riady G, Sabri M, Studi P, et al. Pengaruh pemberian vitamin $E$ terhadap kadar malondialdehida (MDA) serum tikus putih (Rattus norvegicus) diabetes melitus. J IIm Mhs Vet. 2018;2(1):70-6. http://jim.unsyiah.ac.id/FKH/article/view/6760.

46. Fitriana I, Dwi Wijayanti A, Wikan Sari P, Gagak Donny Satria R, Cahyo Budi Setiawan D, Heru Fibrianto Y, et al. Kadar malondialdehid tikus diabetes melitus tipe 2 dengan terapi ekstrak media penumbuh sel punca mesenkimal. Acta Vet Indones. 2017;5(1):29-36. http://www. journal.ipb.ac.id/indeks.php/actavetindones. 
47. Dewi NP, Allia R, Sabang SM. Uji efektivitas antidiabetes Eleutherine bulbusa (MILL.) URB. terhadap penurunan kadar glukosa darah tikus obesitas. In: Proceeding of Mulawarman Pharmaceuticals Conferences. 2016. p. 51-633. https://doi.org/10.25026/mpc.v3i2.88.

48. Tresnawati W, Saputri FA. Review: Analisis penentuan glibenklamid dalam pharmaceutical dosage forms. Farmaka. 2017;14(2):23245. https://doi.org/10.24198/jf.v14i2.10840.

49. Aulani A, Roosdiana A, Rahmah NL. The potency of Sargassum duplicatum Bory extract on inflammatory bowel disease therapy in Rattus norvegicus. J Life Sci. 2012;6(2):144-54. https://www. researchgate.net/publication/26419751.
50. Agrawal R, Sethiya NK, Mishra SH. Streptozotocin-nicotinamide induced type-II diabetes in rats. Pharm Biol. 2013:51(5):635-42. doi: 10.3109/13880209.2012.761244.

51. Patel OPS, Mishra A, Maurya R, Saini D, Pandey J, Taneja I, et al. Naturally occurring carbazole alkaloids from Murraya koenigii as potential antidiabetic agents. J Nat Prod. 2016;79(5):1276-84. doi: 10.1021/acs.jnatprod.5b00883.

52. Tiong SH, Looi CY, Hazni H, Arya A, Paydar M, Wong WF, et al. Antidiabetic and antioxidant properties of alkaloids from Catharanthus roseus (L.) G. Don. Molecules. 2013;18(8):9770-84. doi: 10.3390/ molecules18089770.

\section{GRAPHICAL ABSTRACT}

\section{Longjack (Eurycoma longifolia Jack.)}

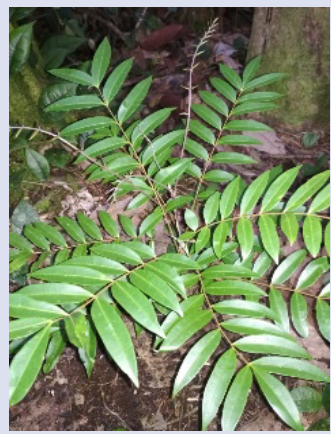

\section{Extracted}

Table 1. Average levels of blood glucose in rats on each treatment group on the day 0,3 , and 18

\begin{tabular}{lccc}
\multicolumn{1}{c}{ Treatment Group } & \multicolumn{2}{c}{ Average Levels of Blood Glucose (mg/dl) } \\
\cline { 2 - 4 } & D-0 & D-3 & D-18 \\
Normal Control & $66.36^{\mathrm{a}} \pm 1.42$ & $67.54^{\mathrm{a}} \pm 1.23$ & $78.73^{\mathrm{a}} \pm 7.20$ \\
CMC-Na 5\% dose 2 ml/200 g body weight & $66.29^{\mathrm{a}} \pm 1.87$ & $277.19^{\mathrm{b}} \pm 3.01$ & $285.84^{\mathrm{c}} \pm 17.56$ \\
Ethanol Extract of Longjack Leaf dose 176.4 & $68.40^{\mathrm{a}} \pm 1.71$ & $281.04^{\mathrm{c}} \pm 1.79$ & $156.77^{\mathrm{b}} \pm 8.49$ \\
$\mathrm{mg} / 200 \mathrm{~g}$ body weight & $67.16^{\mathrm{a}} \pm 2.27$ & $279.28^{\mathrm{bc}} \pm 3.30$ & $148.63^{\mathrm{b}} \pm 23.81$
\end{tabular}

Information: * Same letters shown not significantly different on the Duncan test at $5 \%$

Numbers shown after \pm demonstrated SD (Standard Deviation)

Table 2. Average levels of malondialdehyde on each treatment group on the day 18

\begin{tabular}{lc}
\hline Treatment Group & Malondialdehyde Level \\
\hline Normal Control & $1.13^{\mathrm{a}} \pm 0.22$ \\
CMC-Na $5 \%$ dose $2 \mathrm{ml} / 200 \mathrm{~g}$ body weight & $10.03^{\mathrm{c}} \pm 0.34$ \\
Ethanol Extract of Longjack Leaf dose $176.4 \mathrm{mg} / 200 \mathrm{~g}$ body weight & $3.86^{\mathrm{b}} \pm 0.71$ \\
Glibenclamide dose $0.09 \mathrm{mg} / 200 \mathrm{~g}$ body weight & $3.64^{\mathrm{b}} \pm 1.77$
\end{tabular}

Information: * Same letters shown not significantly different on the Duncan test at 5\%

Numbers shown after \pm demonstrated SD (Standard Deviation) 


\section{ABOUT AUTHORS}

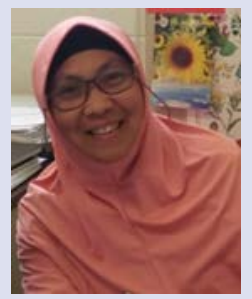

Ruqiah Ganda Putri Panjaitan, graduated from the Department of Biology, FMIPA Andalas University, Padang. She got her masters and doctorates from the Department of Biology FMIPA Bogor Agricultural University. Her field of interest is the study of medicinal plant activity. Now, she is working as a lecturer in Tanjungpura University.

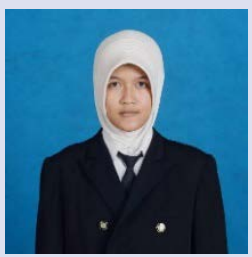

Agus Astuti, graduated from Departement of Biology Education, Tanjungpura University in 2020. Her field of expertise is a Biology Education.

Cite this article: Panjaitan RGP, Astuti A. Antidiabetic Activity of the Leaf Extract of Eurycoma Longifolia Jack. in StreptozotocinNicotinamide Induced Diabetic Model. Pharmacogn J. 2021;13(6)Suppl: 1582-1588. 